\title{
1. Critical theory and the law: reflections on origins, trajectories and conjunctures
}

\author{
Emilios Christodoulidis
}

\section{A BRIEF ARCHAEOLOGY}

The tradition of critical theory has its roots in Hegelian Marxism. While its organising insight can be clearly traced back to Marx, its systematic development, if 'systematic' does not overstate the development of this dispersed and diasporic tradition, does not begin until the end of the First World War. We will look sequentially first at the origins - Marx's profound debt to Hegel and to Feuerbach as expressed in the 1844 Manuscripts and the Theses on Feuerbach respectively - then at a brief history of some of the postwar trajectories of its diaspora. Second, we will identify key moments of the critical-theoretical enterprise, the basic premises of critical theory construction, by providing an inventory of terms and a (necessarily brief) explanation of them: the constitutive relationship of theory to practice or praxis; the dialectic and in particular the moment of negation; the idea of theory's task of mediation as it is situated and embedded in history and the materiality of social reproduction; the genealogical viewpoint; and finally the specific reflexivity that develops and is expressed in and as immanent critique. Third, we will visit these concepts and the ways they interrelate by way of a close reading of Max Horkheimer's essay on 'traditional and critical theory', a text that, despite certain limitations, allows the differentia specifica of critical theory to emerge. Finally we apply these insights to law, to look at whether and how legal method might carry the organising premises of critical thinking into the organisation of law's semiotic field, into legal discourse and legal practice. The analysis here is somewhat skeletal; it falls to the rest of the volume to develop the themes of critical theory along a rich variety of legal trajectories.

Already one is likely to encounter the objection that the critical project was inaugurated by Kant rather than Hegel, because it was Kant who famously answered his own question 'what is Enlightenment' with the injunction 'dare to inquire' ('sapere $a u d e$ '), which releases 'man from his self-inflicted immaturity' by placing knowledge on a critical footing. Hegel objects that Kant's conception of critique is self-defeating. For him, Kant's categorical severance of what is (Sein) from what ought to be (Sollen) undercuts the critical project by withdrawing from it the comprehension it requires to figure as critique. Hegel introduces the dialectic to remedy the devastating disjunction that we might call, with Johan van der Walt, ${ }^{1}$ Kant's incurable hermeneutic deficit, and what from the point of view of critique is an incorrigible incomprehension. We will say

1 See Christodoulidis and van der Walt, 'Critical Legal Studies: Europe', in Dubber \& Tomlins (eds) Oxford Handbook of Historical Legal Research, Oxford University Press, 2018. 
more on this later, in looking at how critical theory promises to recollect the fragments of the 'real' in terms of the 'rational'. In the meantime Hegel invites us to note a second crucial shortcoming of Kant's critical project. What can duty (Pflicht/Sollen) mean for us, he asks, in the realm of pure reason, if it is not conceptualised as a response to the historical circumstances in which we are called to act? The dialectical method is introduced by Hegel to remedy both shortcomings: both to sustain a relationship between what is and what ought to be, and at the same time to locate it within the historical situation, that is, in relation to finite circumstances. Only when embedded in this way does the critical project acquire its necessary purchase in the world. The Marxian notion of immanent critique, as situated in the concrete material practices that reproduce society, pivots on this key insight that emerged from Hegel's critique of Kant.

We will pick up the strand of 'immanence' again, of course, as that which drives critical theory methodologically. But first, to radicalise, with Marx, that first prong of critique regarding the bridging of the domains of 'is' and 'ought', we turn to his engagement no longer with Hegel but with Feuerbach, with whom Marx was in the process of settling his accounts in 1845 when he produced that explosive text that came to be known as the Theses on Feuberbach. It emerges most clearly in the famous '11th thesis', in which Marx argues that '[t]he philosophers have only interpreted the world, in various ways; the point is to change it'. Marx of course does not mean that philosophers should cease to try to understand the world; he means that comprehension engages them in a task whose requirements are significantly steeper than ordinarily assumed. The 11th thesis tells them that their attempt to understand cannot be and should not be divorced and distinguished from an activity that has a certain telos, which alone for Marx yields objective truth. As he puts it in the second thesis: 'The question whether objective truth can be attributed to human thinking is not a question of theory but is a practical question.' Herbert Marcuse, who was influential in introducing the work of the Frankfurt School to the US academy, puts it nicely nearly a century later: 'What exists is not immediately and already rational but must be brought to reason.' 2

We will have a lot more to say about praxis and its relationship to theory in the next section, but we can already discern in the invitation to bring to reason something of an 'active element in cognition', as Max Horkheimer put it. Hegel insists on a distinction between the terms Understanding (Verstand) and Reason (Vernunft) that may help to elucidate the modality of the critical intervention. The activity of 'bringing to Reason' involves an ambitiously synthetic activity that contrasts with the more superficial, commonsensical perception of the givenness of phenomena as discrete and separate entities. Reason asks the question of what is the mode of their individuation, what evaluative criteria are deployed to individuate facts and events that appear as given at the level of simple Understanding: evaluative because they carry a judgement over salience regarding the criteria of selection. And then, to return to Marcuse, now with even clearer echoes of Hegel: 'As the given world [is] bound up with rational thought and, indeed, ontologically dependent on it, all that contradicts reason or is not rational

2 Marcuse, Herbert, 'Philosophy and critical theory', Negations 6.1 (1989): 147-54, emphasis added. 


\section{Research handbook on critical legal theory}

is posited as something that has to be overcome. Reason [is thereby] established as a critical tribunal.' ${ }^{3}$

It would not be an exaggeration to say that these two poles - of reason and praxis are what the dialectic spans, poised to 'probe the forcefield' between consciousness and being, subject and object, in Adorno's formulation. ${ }^{4}$ Adorno along with Horkheimer was at the forefront of the recovery of this Hegelian Marxism as the Frankfurt Institute for Social Research (the 'Frankfurt School'), established in 1923, took a radical turn towards Marxism in the 1930s (only to turn away from it after the Second World War). The rediscovery of the early Marx of the 'Paris Manuscripts' of 1844, a text that was first published more than half a century after it was written, was crucial to the rise of critical theory after the First World War, with its key emphasis on praxis, precipitated by George Sorel's theorisation of workers' spontaneous political action and Rosa Luxemburg's theorising of the auto-gestion of revolutionary workers' councils. ${ }^{5}$ In terms of the philosophical turn to Marx, the great Hegelian Marxist Georg Lukács was hugely influential in the 1920s with the publication of the History of Class Consciousness, as was Karl Korsch with Marxism and Philosophy. These works raised a distinct, and distinctly heterodox, voice against the orthodoxy of the socialist thought of the Third International, critical because of the constitutive connection to praxis (more on this soon) and echoing the early Marx, who had argued, against the givens and assumptions that founded bourgeois society, that in fact the only given was humankind's ability to forever create itself anew.

In this introduction to the rise of critical theory in Europe, both the history of that rise and the theoretical trajectories and work of its protagonists, fascinating as they are, will be kept to a minimum, in order to reserve some space for conceptual analysis. A few words are nevertheless necessary to identify a tradition that stems from the work of Marx in the 1840s and spans a number of generations after him. The annals of critical theory in its European trajectory would include the influential work of Lukács and that of the Italian 'school' (De la Volpe, Colletti), of which Antonio Gramsci was the towering figure. The emphasis in the tradition drawing from Gramsci was predominantly on the political moment of the production of political unity as the latter proceeds through processes of 'condensation' and 'distension' 6 of social forces and the mobilisation of collective subjects which provide the 'efficient cause' of the development of the material constitution - a theme radicalised later in the work of the leftists of the Operaismo and Autonomia movements that emerged out of the Italian trade unions. Perhaps one could extend the reach, though their inclusion is highly controversial given their clear anti-Hegelianism, to a current of critical thought at the École Normale Superieure in Paris, around the leading figure of Louis Althusser - a current that would include Nicos Poulantzas, Étienne Balibar and Alain Badiou, and the recently much

3 ibid 937, emphasis added.

4 Quoted in Jay, Martin, The Dialectical Imagination, University of California Press, 1973, at $\mathrm{p} 54$.

5 Sorel, Georges, Reflections on Violence, Cambridge University Press, 1999/1908.

6 See among others Laclau, Ernesto and Chantal Mouffe, Hegemony and Socialist Strategy, Verso, 1985. 
celebrated work of Jacques Rancière. ${ }^{7}$ The work of Foucault at the ENS developed largely in dialogue with that tradition. But most crucially the key protagonists and representatives of critical theory are the theorists of the Frankfurt School, which emerged during the Weimar Republic when the Institute for Social Research was set up in Frankfurt, and brought within its ambit important thinkers such as Herbert Marcuse, Erich Fromm, Karl Lowenthal and Walter Benjamin, under the directorship of Horkheimer and Adorno. After the war, some of the protagonists returned from exile to the Institute, and their thinking took a 'negative' turn away from the notion that the dialectic might deliver emancipation. After Auschwitz, Adorno would largely surrender political critique to the 'aesthetic turn', while for Horkheimer the prospect of emancipatory action became increasingly remote in the face of the instrumental logic of bourgeois society.

Today critical theory spans a heterogeneous field. On the one hand we have the second and third generations of the Frankfurt School, orbiting the key figure of Jürgen Habermas. Alongside him worked his contemporaries Alfred Schmidt and Albrecht Wellmer, and among the exponents of the third generation were Axel Honneth, Peter Burger, Oskar Negt, Claus Offe and Hauke Brunkhorst. Habermas' highly influential 'communicative turn' was aimed at redirecting critical theory towards a theory of Reason achieved now as mutual understanding, pursued in a political dialogue that, given its conditions, presupposes and aspirationally achieves the equal competence of all who enter it. But democracy in the form of communicative reason arguably gives up on the tradition's Marxist legacy, divesting it of much of its radicalism, to reconcile it, eventually, to law in the form of the 'co-originality' and mutual implication of democracy and rights, public and private autonomy. Pitted against this development we find the critical projects of deconstruction (Derrida infinitely closer to Adorno and of course Benjamin than to Habermas) and other currents of poststructuralist and postmodern thought. Many of these currents are discussed in contributions to this collection.

Perhaps the changes and mutations of critical thought tracked in the above are not only to be expected but are actually faithful to a thinking that locates itself in history, in a way that makes its insights forever partial, provisional and incomplete. For the purposes of gathering the assumptions that are shared by the many currents of critical theory, and that therefore underpin and inform its very identity, its self-proclaimed historicism is one such shared assumption. The term immanence captures this with its understanding of reason as located in history and its refusal to cast reflexivity as something that might lift itself above the situation that informs its iteration. 'Conjuncture' is the term that, in the radical tradition, typically captures both situatedness and opportunity. If immanence is the first pole, the second is the emancipatory element of theory: theory is the activity of 'bringing to reason' by confronting the contradictions and tautologies with the explanatory frames within which they are encountered and which supposedly provide the coordinates of meaningful engagement and action. While how 'immanent critique' navigates this tension is a key theme that we will visit later

7 For competing accounts of the significance of this tradition see Badiou, Alain, 'The adventure of French philosophy', NLR 35 [2005] 67-77, and Lecourt, Dominique, The Mediocracy: French Philosophy since the Mid-1970s, Verso, 2002. 


\section{Research handbook on critical legal theory}

on, for present purposes we note that in the move that invokes, confronts and potentially transcends the context of its iteration, critique places itself on a certain boundary. In its insistence that the givenness of phenomena, the ways in which the fragmented world installs itself as the necessary context of action, may be navigated, critical theory renegotiates the boundary between contingency and necessity. In the third section of this chapter we will see that Horkheimer identifies 'necessity [as] a critical concept' ${ }^{8}$ that 'contains a protest against the order of things' ${ }^{9}$ By this he means that its reach is not given, but that it harbours political contestation ('protest') by those whose horizon of action it reduces. The term 'liminal' connects the critical insight with thinking the border, in an understanding of 'liminality' as that which concerns the distribution of necessity and contingency across it.

Despite the continuities we are in the process of tracking, there is one staggering difference between the earlier generations of Marxist thinkers on the one hand, and the exponents of Western Marxism after the First World War on the other. It has to do with the question of revolutionary agency, or how to conceptualise the subject of praxis. Between the 1840s and the 1920s, the working class was the projected bearer of the revolutionary project. At the time of the resurgence of critical theory after the war, the subject was already becoming a question to itself. As the issue of how to conceptualise revolutionary agency under conditions of the rise of mass culture, the multiple fragmentations of the working classes across the globe, anti- and postcolonial struggle, and so on became increasingly problematic, critical theory took two different directions, both Hegelian, but of a radically different tenor. In the first, more mainstream expression, the question of agency is recast as a struggle for recognition, with a view to exploring the structures of reciprocity and agonistic engagement that embed actors in social contexts and habitats. ${ }^{10}$ In the second, more radical marxisant expression, with an emphasis not on agonism but on antagonism, the critical gaze largely turned away from theorising the 'subject' and towards theorising the 'event' of revolutionary action. Alain Badiou is a recent example of this tendency, ${ }^{11}$ while for Jacques Rancière, who is much closer to the Hegelian roots (and Lukács' idea of an emergent subjectivity), it is in the event of staging resistance that revolutionary agency is enacted. ${ }^{12}$ It may be worth noting here that Rancière's intriguing turn owes much to his resistance to the lesson of his teacher Althusser, ${ }^{13}$ and he dedicated much of his earlier ethnographic work to recovering the workers' own revolutionary voice in order to let them, so to say, speak for themselves. Against Althusser's dogged structuralism, where the 'subject' is never more than the surface phenomenon produced by the structure (the 'absent

8 Horkheimer, Max, 'Traditional and critical theory', in Critical Theory: Selected Essays, Continuum, 1932/1976, p. 230.

9 ibid 229.

10 Honneth, Axel, The Struggle for Recognition: The Moral Grammar of Social Conflicts, MIT Press, 1996.

11 Badiou, Alain, Being and Event, A\&C Black, 2007.

12 Rancière, Jacques, Disagreement: Politics and Philosophy, University of Minnesota Press, 1999.

13 Rancière, Jacques, Althusser's Lesson, Continuum, 2011. For his return to the Marxism that Althusser rejected, see Rancière, 'Le concept de critique et la critique de l'économie politique des "manuscripts de 1844" au "Capital", in Lire le Capital, PUF, 1998. 
cause'), and where the subject position that the proletariat is 'called' to inhabit is an ontological support or 'placeholder' in a field that 'always-already' represents the economy of capital, ${ }^{14}$ Rancière's is an attempt to carve out another stage for revolutionary agency. The struggle for recognition here, unlike in Honneth and the later Frankfurt School(s), involves 'a class giv[ing] itself a name, in order to exhibit its situation and respond to the discourse of which it is the object'. ${ }^{15}$ The reflexive name-giving, however improbable, is set against the recursive folding back into the processes of misrecognition that underlie identity formation under capitalism. The significance of these acts of forging speaking positions against available distributions must be borne in mind today: they are key to how the critical project understands the processes of subject formation, and the distribution of attention and disregard that they entail.

\section{AN INVENTORY OF TERMS}

This section looks at terms that are pivotal to the conceptual range and novelty of critical theory. It attempts to provide an understanding of them, and track key interdependencies between them.

\subsection{Praxis}

Critical theory borrows the term for 'action' from Aristotle, who distinguishes praxis from the contemplative theoria. But it realigns it: praxis is no longer contrasted with theory, as in Aristotle, but dialectically tied to it in a relation of mutual constitution. In this relation neither concept precedes the other: 'the old question - which has priority? - is meaningless as it is posed', insisted Marcuse. We saw in discussing the 11th thesis that, against the reduction of reason to surface understandings that 'interpret the world', Marx argued that reason was properly deployed in thematising the 'existent' with the view to forging social change. ${ }^{16}$ The thematisation calls forth the facts and events as relevant to the telos of restoring rationality to a 'sunken' world, if we can extend Schelling's beautiful formulation to capture something of the ruinous effects of capitalism. ${ }^{17}$ Against the irrationalities with which class society is fraught, irrationalities that emerge as contradictions, tautologies and impasses, against the irrationality of

14 See Althusser, L., Lenin and Philosophy, New York, 1971.

15 Faure, A. and J. Rancière, La parole ouvrière, Paris, 2007, p. 9.

16 The connection is clearly a great deal more subtle than what Ernst Bloch, the highly original Marxist theorist, found 'misconstrued' in America under the banner of pragmatism, 'which derives from an area altogether remote from Marxism, spiritually inferior, and indeed alien to it', despite the fact that it is being 'constantly latched on to, as though it were identical to American cultural barbarism. The basis of American pragmatism is the view that truth is essentially nothing more that the social utility of ideas.' Bloch, Ernst, On Karl Marx, Verso, 2018/1968, p. 90.

17 'Does not everything announce a sunken life? ... The whole earth is an enormous ruin, whose animals dwell in it as ghosts, and men as spirits, and where many hidden forces and 
a system that promises justice as it relentlessly delivers injustice, the aim of the philosopher of the 11th thesis is to restore a properly human rationality. On the one hand, theory equips practice with its coordinates; on the other, practice situates and resituates theory within new coordinates that will inform its possibilities anew. A dialectic develops between theory and practice in a dynamic process that is caught up in history and in the making of history.

The theory/practice distinction installs a border between the two terms, across which the dialectic operates. The boundary is, so to say, that which gives traction. Theory measures itself against its ability to rationalise practice, and practice emerges as meaningful with the help of theory. The dialectic keeps them combined and in tension. Any asymmetry that installs itself between theory and practice can work both ways. A deficit on the pole of practice leaves theory as mere contemplation of, and apology for, the status quo; a deficit on the side of theory leaves practice underdetermined. The latter is a more difficult deficit to appreciate, so an example might be helpful - an example, that is, of theory failing to give adequate expression to praxis as selfdetermined activity. In The Making of the English Working Class, Edward Thompson described the communities of handloom weavers in Lancashire and Yorkshire at the end of the eighteenth and the beginning of the nineteenth centuries that sustained independent forms of production and exchange "without the distortions of masters and middlemen' 18 but were unable to protect and maintain those forms in the face of the advancing capitalist economy. Alasdair MacIntyre makes the important point that what these communities lacked was a 'theory that would have successfully articulated their practice' of solidarity in the organisation of production and that would have equipped them epistemologically to resist the supposed inevitability of the defeat of their very own principles of association emerging out of jointly held conceptions of the common good. They lacked the theory that would help them to articulate, as he puts it, 'virtues adequate to the moral needs of resistance'.$^{19}$ The demands placed on theory are steep here, and for MacIntyre it is not Marxism that will meet them. Because if Marx offers a theory of resistance for the weavers - he was indeed impressed by the militancy of the uprising of another community of weavers, in Silesia in 1844 - it engages them as proletarians, a constituency incongruous to them in their professional association, not attuned to the life form that made their engagement and resistance meaningful, and, crucially, one that already assumes the defeat of their form of past life. I am reminded of a similar deficit that Tom Nairn attaches to the 'revolutionary explosion' of May 1968. If 1968 failed, he says, it 'failed because it was too novel, and inevitably dwarfed most of the circumstances around it. It was heavy with a significance too great for our times to bear, a premonitory significance which the events of May could only sketch in

treasures are held fast as if by unseen powers or magic spells.' Schelling, Werke, 1927, quoted in Anderson, Considerations of Western Marxism, p. 81.

18 Thompson, Edward Palmer, The Making of the English Working Class, Open Road Media, $1963 / 2016$, at p. 295.

19 In the 1994 text 'Theses on Feuerbach: a road not taken', included in K. Knight, The MacIntyre Reader, 1998, at 232. This point is also developed in MacIntyre, A., 'Epistemological crises, dramatic narrative and the philosophy of science' The Monist 60 (1977): 453. 
outline.' ${ }^{20}$ How eloquent the incomprehension that attaches to that surge of collective action: of an event that broke with the theoretical models available to interpret it. Practice here was in advance, to paraphrase Rimbaud on the Paris Commune. And the responsibility that befalls theory, once conscious that it lags behind, is to lend praxis expression in terms that are adequate to it, and in time that is still opportune!

If the unity of theory and praxis is what is distinctive of Marxist method, it is also what threads together the variants of critical theory, and collects the tradition around a common premise. So far I have attempted to show how the connection can be conceived at the level of conceptual analysis and the rationalising, emancipatory gesture (that is, action) of the theoretical undertaking. But there is a second level at which the connection between theory and praxis is forged, and this level explicitly links theory to collective action. It can be read in Marx's own rejection of pure theoretical work as a means of social change, ${ }^{21}$ his conception of a humanism that comprehends itself in action. And it is renewed and enhanced in the insistence that the unity of theory and practice finds its culmination and completion in the mass revolutionary movement. If today this connection, with few exceptions, appears increasingly remote (see section 1), one must remember that for the generation of thinkers that immediately followed Marx and Engels the connection with practice was part of the lived reality of theoretical engagement; clearly in the case of Lenin and Luxemburg, of course, but also for the subsequent generation, among whom Lukács wrote the constitution of the Hungarian communist party and Gramsci organised the workers' insurgencies of 1919 and 1920, when he led the Turin factory councils, and then founded and led the Italian Communist party in the mid-1920s. ${ }^{22}$ The examples are numerous. It was only after the Second World War and perhaps, ironically, with the Frankfurt School of Critical Research itself that had proclaimed with Adorno that 'theory is a form of practice and practice itself is an eminently theoretical concept' ${ }^{23}$ that the connection with praxis was renounced, while the communist parties of Europe's South sustained an often difficult relationship with 'their' theorists (as for example in the tense relationship of Althusser to the PCF). And yet the connection with practice remains the task against which critical theory measures itself, not in the relatively easy lexical identification ('theory is practice') but in the difficult articulation that demands a certain synchronicity between the two, that demands, in other words, that theory does not outpace the real historical rhythm of popular mobilisation or substitute for the masses' own modalities of engagement and self-understanding, while remaining alive and relevant to those processes.

\footnotetext{
20 Quattrocchi, Angelo, and Tom Nairn, The Beginning of the End: France, May 1968, Verso, 1998.

21 'Just as philosophy discovers its material weapons in the proletariat, so the proletariat discovers its intellectual weapons in philosophy' (a contribution to the critique of Hegel's Philosophy of Right).

22 For Perry Anderson, 'it is a token of his greatness' that Gramsci 'alone embodied in his person a revolutionary unity of theory and practice, of the type that had defined the classical heritage'. In Anderson, Considerations of Western Marxism, Verso, 1976, p. 45.

23 Adorno, T, Negative Dialectics, Routledge, 1966/1990, p. 144.
} 


\subsection{The Dialectic and the Role of Negation}

While the dialectic is absolutely central to critical theory, even at the outset a question presents itself over its designation as method or system. ${ }^{24}$ 'System' ties it too closely to Hegelian philosophy, where it receives its most profound statement but at the same time becomes locked into a logic of history; 'method' on the other hand invokes means-ends thinking that not only belittles its constitutive (rather than instrumental) significance to critical theory but also begs the question of what ends critical theory deploys the dialectic as the means of. However we describe it, nevertheless it is the dialectic that lends critical theory its very dynamic, and places it within the movement of history that it is tasked to at once understand and intervene in.

Against both the metaphysics of systematic philosophy, of which Hegel's was the last major iteration, and empiricism's invitation to the 'commonsensical', critical theory invites the observer to hold up to reason the givens of experience, the understanding of factual situations, replete as they come with antinomy and contradiction. No fact situation is to be deemed final or complete in itself, but always should be seen as an instantiating aspect of the total situation as it is caught up in historical change. 'Men make their own history', Marx famously remarked in the 18th Brumaire, 'but not under conditions of their own choosing'. Theory delineates that which opens up meaningfully as the field for praxis, the constraints it must navigate and the vistas it may yet uncover. For the interplay to be maintained, the gravity of the factual situation, the 'mere immediacy of the empirical world' (Lukács), needs to be suspended for alternatives to be glimpsed and, once comprehended, acted upon. This glimpse - the 'Augenblick' takes, in Lukács, an altogether different significance, ${ }^{25}$ but we cannot presently follow him along that path.

We will remain instead with the significance of the negative in the unfolding of the dialectic. The dialectic, as is well known, moves from an initial positive (thesis) through its rejection (antithesis) to a transcendent synthesis or 'sublation' (Aufhebung in Hegel) that maintains both moments, and preserves the transcended in the act of overcoming it. These, for Hegel, are the markers of the unfolding of reason in history, and the concept of negation, while crucial to that unfolding, is nonetheless transitory, subject in turn to its own negation as history moves forward towards its telos. Against Hegel's projection of this smooth passage through the negative, Marx fastened onto the contradictions that persisted in the reality of capitalism, identifying negation as constitutive to the formation of subjectivity (degradation reaches its acme with the dehumanisation and objectification of the proletariat: the negative form of absolute deprivation of the 'Nothing that would become Everything'), ${ }^{26}$ and suggesting leverage in the unresolved contradiction that - as negation - sets reality against itself.

24 On this see Jameson, Fredric, Valences of the Dialectic, London, Verso, 2009.

25 Lukács, Georg, History and Class Consciousness: Studies in Marxist Dialectics (R. Livingstone, trans), London: Merlin, 1971/1923.

26 See Marx, A Contribution to the Critique of Hegel's Philosophy of Right. On the constitutive role of negation see also the chapter on critical legal theory and Marxism in this volume. 
Taking up Marx's insight, the theorists of the Frankfurt School also fastened onto the moment of negation, and insisted on viewing critical theory as the site of the negative thrust of Reason. In their earlier work, indeed, the critical impulse sustained itself in its opposition to the order of society as it appears, insistent on the nonidentity of the actual and the rational, and installing itself, as intervention, in that faultline between the two. 'A given social order based upon a system of abstract labour and the integration of needs through the exchange of commodities is incapable of asserting and establishing a rational community', argued Marcuse. The contradiction cannot be 'sublated' by means of pursuing the systemic logic of bourgeois society; it requires a utopian moment (utopian because unavailable in the given situation) and therefore a commitment to negativity. Horkheimer will also warn in 1942: 'Dialectics is not identical with development ... [Social revolution] is not the acceleration of progress but rather the jumping out of progress [der Sprung aus dem Fortschritt heraus].' ${ }^{27}$ And later: 'The new society arises from praxis. It goes back to 1871,1905 , and other events. The revolution has a tradition on whose continuation theory is dependent.' 28

But where Marxism never abandons the idea that the extreme degradation and alienation visited on the proletariat will become the point of dialectical reversal, the critical theorists of Frankfurt - writing in the shadow of the rise of Nazism - came largely to abandon the idea that an emancipatory dialectic might be forged out of the situation they faced, and became increasingly insistent on the moment of negation without sublation. In other words, where the conditions offered no possibility of being put to question against any credible alternative or potentiality, the dialectic was blocked. ${ }^{29}$ Horkheimer wrote in The Eclipse of Reason that inasmuch as subject and object, word and thing cannot be integrated under present conditions, we are driven by the principle of negation to attempt to salvage relative truths from the wreckage of false ultimates'.30

\subsection{Mediation and Ideology}

We will remain with the meaning and use of negation but generalise it beyond the extraordinary circumstances of the rise of fascism, and across the very ordinary operation of capitalist social reproduction. In a letter to Carl Lowenthal in 1934, Adorno wrote of 'the agonising development of the capitalist total situation whose

27 Quoted in Jay, The Dialectical Imagination, p. 157.

28 Horkheimer, Max, Autoritärer Staat: Aufsätze 1939-1941, de Munter, 1967, at p. 138.

29 'Their legacy would be to place the very notions of historical subjectivity and the idea of an emancipatory dialectic between subject and object in question. Their coauthored essay on The Dialectic of Enlightenment (1944) already commenced with an equation of subject-formation and reification. The subject itself is as such a product of reification and dominance and can therefore not be invoked for purposes of contemplating a revolutionary de-reification of social relations, they argued. Negative Dialectics (1966) is one of the crucial statements of critical theory's despairing withdrawal from the philosophy of the subject.' Christodoulidis \& Van der Walt, 'Critical legal theory: European perspectives', in The Oxford Handbook of Legal Research (forthcoming).

30 Horkheimer, Max, The Eclipse of Reason, Continuum Books, 1974/1947, at p. 183. 


\section{Research handbook on critical legal theory}

horrors exist so essentially in the precision of the mechanism of mediation'. ${ }^{31}$ We are already familiar with the term 'mediation' and what it expresses for us. Here are some examples: the operation of the capitalist economy and the material reproduction of society are constitutively mediated by legal, political, moral and economic concepts that simultaneously organise the network of commodity exchange and give it expression as the coordination of acts of freedom and autonomous agency; the operation of the labour market that secures the extraction of surplus value is expressed as freely contracted labour, and so on. There are key features of material organisation of society that are thereby distorted, misrepresented, eclipsed or elided in the process of giving them expression. Critical theory here measures itself against the operation of ideology.

If ideology in common parlance usually means a body of ideas and beliefs, in the understanding of critical theory it is related to a function. This function is to sustain relations of domination through a move at the level of representation. ${ }^{32}$ Marx invites us to think about how real relations are represented and lived, and locates ideology as that system of representation that mediates man's relationship to the material conditions of his life. Ideology here names a certain misrepresentation, a certain misreading of the conditions that allows the continuation of a system of domination that presents itself as free. As John Thompson has put it:

the concept of ideology calls our attention to the ways in which meaning is mobilized in the service of dominant individuals and groups, that is, the ways in which the meaning constructed and conveyed by symbolic forms serves to establish and sustain structured social relations from which some individuals and groups benefit more than others. ${ }^{33}$

There is a connection here between material production and the control of intellectual production, but that is not all. Ideology covers the multitude of ways in which capitalism diffuses resistance and critique through subtle moves and strategies at the level of representation. To reproduce itself over time, capitalism must ensure that relations of production are reproduced, and that class struggle is prevented from irrupting in a way that might challenge the capitalist distribution of advantage.

Our earlier insistence on negation, and the stance of 'being-against' that it informs, can be comprehended as levelled against the ways in which systems of meaning and dominant representations are mobilised ideologically to install false givens and assumptions at the point of recovery of the meaning of the possibilities of association. Critical theory faces a difficult task against the pervasiveness of ideology, especially when the dominant interests it serves combine in hegemonic constellations. ${ }^{34}$ Organised and transmitted through the network of predominantly cultural institutions, the system

\footnotetext{
31 In Jay, The Dialectical Imagination at p. 66, my emphasis.

32 Here is Marx in The German Ideology: 'The class which has the means of material production at its disposal, has the control at the same time over the means of intellectual production, so that thereby, generally speaking, the ideas of those who lack the means of intellectual production are subject to it.' (1846/1932, p. 176).

33 Thompson, John B., Studies in the Theory of Ideology, University of California Press, 1984 , at p. 73.

34 For the meaning of hegemony see Gramsci, Antonio, Prison Notebooks, Columbia University Press, 1992/1931.
} 
of power becomes hegemonic to the extent that it can minimise the level of repression it requires in order to secure its continuation, because the organisation of the totality of dialectical mediations in such constellations extracts allegiance and secures consent. How, asks Marcuse in One-Dimensional Man, ${ }^{35}$ might the negative thrust of reason be asserted in a society that thus controls the consciousness of its members? Ultimately its achievement will be to allow language to voice the protest of the oppressed, and prevent it from mutating into a stream of affirmations or at best concessions before 'false ultimates'. Our discussion has revolved around the question of how a critical reflexivity might be forged out of these inert or suppressed material, the resources of the society in which we find ourselves, the ideas, stock of meanings, interpretation of history and imaginaries that contain them: a critical reflexivity that may be able to resist the reproduction of the systemic givens.

Critique strives to put itself at some distance from the conceptual forms that determine identity and action, if what is given over to 'understanding' (Verstand) by the dominant imaginary is to be prevented from establishing itself as unquestioned and unquestionable context for thought and action. In a crucial sense this involves the introduction of contingency where there is necessity. Certainly, as we discussed already, the reflexive move is emphatically not a stepping outside of the context that might afford an objective (as opposed to class-inflected) view, but always carries the partiality of contextually situated and historically conditioned perspectives. But where founding assumptions carry self-evidence into the imaginary constitution of society by mobilising specific systems of signification and material support, critical theory demands the recognition of the contingency of those foundations. This is both key to critical thinking and one of its steepest requirements - one that Althusser, for one, thought impossible in relation to the fundamentals of capitalist relations. ${ }^{36}$ Marx's analysis of the fetish phenomenon was for him a case in point: if the commodity form installs itself from the outset as the very way in which we conceptualise social relations, action and agency, then they cannot be stepped behind to recover them in a nonalienated form.

The distinction in fact of what is necessary and what contingent lies at the heart of the task that critical theory sees itself as addressing, sometimes described as 'antinecessitarian' thinking. ${ }^{37}$ The idea is to resist the temptation to describe the realm of freedom from the vantage point of (supposed) necessity; to resist the argument, typically, that given human nature, such are the options available for the exercise of freedom. Famously, for example, Thomas Hobbes extracted the reason for the constitution of civil society from the givenness of human nature. The granting of absolute sovereignty to the Leviathan connects to what motivates human behaviour -

35 Marcuse, Herbert, One-Dimensional Man: The Ideology of Advanced Industrial Society, Sphere Books, 1964.

36 For Althusser's rejection of the Hegelian tradition and the direct reconnection with the scientific theory of historical materialism, see Reading Capital. For Althusser, Hegelian 'historicism was a ideology in which society becomes a circular expressive totality, history a homogeneous flow of linear time, philosophy a self-consciousness the historical process, capitalism a universe essentially defined by alienation, communism a state of true humanism beyond alienation.' See Anderson, Considerations on Western Marxism, p. 70.

37 See e.g. Unger, Roberto Mangabeira, False Necessity: Anti-Necessitarian Social Theory in the Service of Radical Democracy, Cambridge University Press, 1987. 


\section{Research handbook on critical legal theory}

fear, given the nature of man that makes '[him] wolf to man' and the 'natural state' as that of 'constant fear, and danger of violent death; and the life of man solitary, poor, nasty, brutish and short'. An argument that begins with the supposed 'givenness' of the nature of 'man' and what moves him allows the constitution of civil society to be understood as coincident with its subjugation to the sovereign. In other words, at the point of the recovery of the meaning of civil society, a point that cannot be stepped back from, is installed the necessity of its subjugation. The assumptions over necessity, whatever their content, across the theories of social contract premise the 'political' on necessary assumptions about human nature. To this Marx responds with an argument that attributes near infinite plasticity to the possibilities of human association.

But to return to the key term under scrutiny, the focus and stake of 'mediation' are the processes of meaning construction. If, as we read it above, the 11th thesis aimed to elevate Understanding to Reason, it was because understanding of the world, the observation of reality, is never immediate to itself; it is instead mediated through categories, structures and conceptual schemes. These mediations are of course abstractions; they select and classify the 'raw' material of observation, individuate events, establish causal connection, generalise specific features of the situation while suppressing others, and in that mediation they configure the real. The creation of meaning occurs in terms of specific imaginaries, with their vocabularies and rules of signification. It also occurs in the context of specific sets of social relations, institutional arrangements and processes of social reproduction. In both senses meaning construction is always in media res: situated in history, partial and perpetually incomplete. It may appear surprising that critical theory directs us to the mediating function that involves abstraction, since Marx famously denounced precisely capitalism's transformation of concrete labour into 'abstract labour', the concreteness of social life into the abstract lawlike forms of exchange-dependent civil society. But what Marx was denouncing in these abstractions was not abstraction itself, which is a constitutive moment of thought, but the specificity of bourgeois abstractions that involve specific substitutions: of use value for exchange value, of living labour for dead labour, of social being for individualism, and so on. Critical theory calls for attention to the fact and the nature of mediation; understands it as historical and therefore as revisable; and in that sense is both attuned to the ways in which social change might be pursued and more importantly attuned to the distinction between what is contingent, and could therefore be thought of, thematised and undertaken otherwise, and what is not.

But if negation invites us to resist ideology and hold the present up to reason, because it divests realities of the self-evidence with which they present themselves to our understanding, it fulfils a similar function when it comes to the past. Here the emphasis of the critical project is on how reason fixes its gaze on, and uncovers, the past. For this we turn to another important concept of the lexicon of critical theory, that of genealogy. 


\subsection{Genealogy}

'A true dialectics was the attempt to see the new in the old instead of simply the old in the new', wrote Adorno in the Metacritique. ${ }^{38}$ This is clearly not a statement to the effect that 'history matters', as easy references to the notion of genealogy so often assume. It is instead a dialectical intervention in the temporal dimension of the present/past: it alerts us to the fact that every new constellation that we inhabit as political actors repositions us before the challenge - and renewed capacity - to read the past as it becomes available to our understanding at each turn. This repositioning introduces a new level of contingency across the temporal dimension of meaning construction. It works against the assumption that the contingency of the future is set before and against the determinism of the present and the past. Instead the 'active' role of the contestation of the past in the present sets the latter, too, on a contested basis; a certain fluidity is introduced across both borders (past/present/future) and along the entire axis of the temporal. And if genealogy is often associated with 'subjugated knowledges', as the literature on and around Foucault frequently reminds us, it is the disruptive thrust of genealogy that allows their recovery against the way in which dominant historical trajectories establish lineages and causal continuities that 'subjugate' them.

'What I would call genealogy', Foucault famously wrote in 1977, '[is] a form of history which can account for the constitution of knowledges, discourses, domains of objects, etc, without having to make reference to a subject which is either transcendental in relation to a field of events or runs in empty sameness throughout the course of history'. ${ }^{39}$ For Foucault (who takes his inspiration from Nietzsche), 'there is nothing primary to interpret': everything is already interpretation. If genealogy is a history of the series of interpretations, it is also a history of how things have come to be seen as objective. The genealogist, Foucault puts it memorably, is tasked with 'recognis[ing] the events of history, its jolts, its surprises, its unsteady victories and unpalatable defeats'; tasked with understanding the 'hazardous play of dominations' 40 against what comes to install itself as the apparent objectivity of the present. That is why Foucault's emphasis is on the events of history, and that is why his genealogy is disruption: a contingency read back into histories to destabilise them at the junctures where they assert objectivity and constitute themselves as a knowledge. Let us be clear about this point of method: the genealogical coupure allows us to cut into historical trajectories to look at how, at crucial junctures, certain options were discarded and certain options were installed as conditions of the range of further developments. With attention focused on how discourses harness the power of truth, genealogy points to the contingent constitution of those objectivities. Accordingly, a profound possibility and urgency attaches to the genealogical method: urgency because histories - in their paradigmatic form - are caught up in trajectories that offer nothing as alternative; and profound possibility because genealogical method holds the historical framework itself

38 Quoted in Jay, The Dialectical Imagination, at p. 69.

39 Foucault, Michel, Language, Counter-Memory, Practice: Selected Essays and Interviews, Cornell University Press, 1977, p. 144.

40 ibid, p. 148. 
to question in a way that both exposes the points of foreclosure on which current certitudes depend, and directs historical insight back to the discarded histories of those certitudes.

Foucault's genealogy is tied to what he calls the archaeological method. What the archaeology 'excavates' along the temporal path-dependency of meaning are the junctures where determinants set the present on its path. It asks: what were the possibilities and contingencies that might have been thereby passed over, elided or obscured? And while Foucault was most interested in uncovering the histories of discursive formations as a series of interpretations on which 'violent or surreptitious' direction was 'imposed', ${ }^{41}$ he points critical theory in the directions of what it means to reappropriate the past, 'bend it to [a different] will' and restore it to alternative interpretations that might challenge current certitudes; to return the past, as it were, to its potentiality. ${ }^{42} \mathrm{~A}$ critical intervention of this kind addresses the question of the conditions of possibility of the formation of knowledges; it addresses, in other words, the gathering work that explanatory frameworks and contexts perform, with their specific forces of rationalisation at play. Rationalisation would include here the range of classifications, causalities, imputations, the array of techniques of selection, through which the past is rendered operative for the present. And in a move that today we associate with the notion of deconstruction, it attempts to trace their genesis and operation; if the past is going to be released from such determination, to question their functionality; and, if negation is still what drives critical intervention, to thereby render them inoperative. Only in this way will the foreclosing of options be resisted, and an enhanced reflexivity restored to the present in a way that equips it to revisit the distinction between necessity and contingency outwith the seemingly intractable path-dependencies that hold the present captive to the past.

\section{IMMANENT CRITIQUE: THEORY AS 'GENUINE FORCE'}

In Max Horkheimer's essay of 1932, ${ }^{43}$ traditional and critical theory are contrasted in a series of stark binaries. The inaugurating move of traditional theory involves the separation of questions of fact from questions of value, research from evaluation, description from prescription. In 'traditional theory', conceptual systems (methodologies) that organise our knowledge of the world receive correction according to their own criteria of salience and weight, in accordance, that is, to their capacity to sustain their own internal coherence. The observer perceives herself as passive in the act of reception, as if, says Horkheimer, s/he brings nothing to the process. At the same time the perceived fact stands independently of the act that recognises it as fact. For

41 To quote the passage in full: 'If interpretation is the violent or surreptitious appropriation of a system of rules, which in itself has no essential meaning, in order to impose a direction, to bend it to a new will, to force its participation in a different game ... then the development of humanity is a series of interpretations' (Foucault, 'Nietzsche, Genealogy, History').

42 Returning the past to its potentiality is the aspiration that sustains Agamben's method in Signatura rerum. Sur la méthode, Vrin, 2008.

43 Horkheimer, 'Traditional and critical theory'. 
Horkheimer, this dual misapprehension misses the crucial insight that 'facts which are presented to our senses' are 'socially pre-formed in two ways: through the historical character of the object perceived and through the historical character of the perceiving organ'. ${ }^{44}$ The perceived fact is, in effect, codetermined by ideas and concepts. The act of perception is clearly connected, says Horkheimer, with material processes of production that effect 'the mediation of the factual through the activity of society as a whole' ${ }^{45}$ But it is 'easy at this point to confuse two questions: the mediation of the factual through the activity of society as a whole, and the question of the influence of the measuring instrument'. ${ }^{46}$ Both are relevant but in distinct ways. 'As man reflectively records reality, he separates and rejoins pieces of it, and concentrates on some particulars while failing to notice others.' It is these processes of selection, of disassembling and reassembling the 'pieces', with the full complement of anticipatory assumptions, projected path-dependencies, and 'hidden conflicting forces', that Horkheimer suggests that 'traditional theory' misses or elides in the perception and representation of the world of ordered concepts that forms its object. Take bourgeois society, he suggests, 'in which the life of the society proceeds from the economy only at the cost of excessive friction, in a stunted form and almost, as it were, accidentally'. ${ }^{47}$ The problem is, he says with extraordinary foresight, that 'contemporary political economics are unable to derive practical profit from the fragmentary questions they discuss'. 48

Against the fragmentation that pervades traditional theory, a fragmentation that is constitutive of the fundamental divisions (fact/value, subject/object) through which it operates and therefore unaddressable by it, Horkheimer will invite the critical recuperation of reason. The critical engagement 'leads to a re-assignment of degrees of relative importance to individual elements of the theory, forces further concretisations and determines which [scientific insights] are significant for critical theory at any given time'. ${ }^{49}$ 'The world that is given to the individual is the product of the activity of society as a whole.' 50 A crucial insight about the unity of theory emerges in this suggestion of the recuperation of reason. In the face of everything that has been said about fragmentation above, the unity of theory is only achievable vis-à-vis the unity of the situation that confronts it. This dialectical tie is crucial for the role of theory that confronts, under capitalist conditions, a reality riddled by contradiction, in other words a reality that cannot be theorised as a unity. And the importance of this insight is this: the fact that theory in its current conjuncture cannot achieve the sufficient level of internal coherence vis-à-vis contradiction does not make it deficient; instead the recuperation of reason forces the theoretical undertaking not in the direction of internal critique and the readjustment of its own methodological assumptions, but in the

\footnotetext{
44 ibid 200.

45 ibid 201.

46 ibid 200-1.

47 ibid 203.

48 ibid 228.

49 ibid 234.

50 ibid 200.
} 
direction of making rational the disunity that confronts it, equipped now with the reality-transforming force of immanent critique.

What would the self-awareness of thought ${ }^{51}$ - what we have called its reflexivity achieve confronted with its object under conditions of fragmentation, substitution, and so on - conditions, that is, of disunity? How might this stunted reflexivity - available to 'understanding' - be recuperated as self-awareness in the reflexivity of reason? Since 'theory [as] a unified whole has its proper meaning only in relation to the contemporary situation',52 the task against which the critical attitude measures itself is to achieve 'its proper meaning' by addressing in a coherent way what in effect confronts it as a dispersal of social totality. Inevitably theory will be drawn into an 'evolution' as a result. It might be useful to note that this was never an issue for Kant's critical enterprise. For Kant, the primary transcendental move of critical thought, which is the transcendental condition of knowledge, presupposes the existence of its object and reflects on the a priori that conditions the possibility of our knowledge of it. To Kant the question of the 'evolution' of theory in tandem with the reality it comprehends is in any case lost, since the things-in-themselves are unavailable to perception and to any sense of equivalence to the concepts that mediate them. To Hegel the transcendental moment, the overcoming of Reason's limitation, is a matter of history or of the 'cunning of reason'. It is only with the Left-Hegelians, and Marx in particular, that 'reason comes to stand over against itself [that is, over against its instantiations] in purely critical fashion'. ${ }^{53}$ The Hegelian moment allows us to recover the critical vein in Marxism from the standpoint of its own philosophical foundation.

But we do not need to dwell further on the philosophical foundations for present purposes. Instead, let us return to the task that philosophical critique sets itself in view of the thesis, Marx's 11th thesis, that lies at its root. All theory, critical or traditional, derives its statements about real relationships from basic universal concepts. But unlike traditional theory, in critical theory these universal concepts do not install themselves on one side of the distinction between diagnosis and cure, description and prescription, but on the boundary itself. Because if in traditional theory the object is not affected by the theory that describes it, critical theory casts its descriptions (its universal concepts) as relevant to its own emancipatory function vis-à-vis necessity. That is why Horkheimer says that 'a consciously critical attitude is part of the development of society'; because the diagnosis of the pathology is not independent of its overcoming. The judgement passed on the 'necessity' inherent in the previous course of events engages also a struggle to change it from 'a blind to a meaningful necessity'. Hence for Horkheimer, as we saw, 'necessity is a critical concept'; 54 and that is why 'it contains a protest against the order of things' ${ }^{55}$ Where in traditional theory 'necessity means the independence of the event from the observer', 56 critical theory as the 'tribunal of

$\begin{array}{ll}51 & \text { ibid } 209 . \\ 52 & \text { ibid } 238 . \\ 53 & \text { ibid } 204 . \\ 54 & \text { ibid } 230 . \\ 55 & \text { ibid } 229 . \\ 56 & \text { ibid } 230 .\end{array}$ 
reason' theorises a world in which the necessity of an object becomes the necessity of a 'rationally mastered event'.

And that is also why 'the tension between the concept and being', theory and the social world, 'is inevitable and ceaseless'. Critical theory installs itself in the instituting gap between the two and what drives it is not some speculative commitment to coherence, but to a deficit that is experienced by social actors, as alienation. 'The critical theorist finds himself confronted with the real experience of disharmony or alienation.' The transmission of theory is aroused by prevailing injustice, says Horkheimer, 'today, when the whole weight of the existing state of affairs is pushing mankind towards the surrender of all culture and relapse into darkest barbarism'. ${ }^{57}$ Much of Horkheimer's critical enterprise is directed to tracking the 'productive' tension between processes he deems 'objective' and the 'subjective' experience they generate in those who find themselves subject to them. The embeddedness in experience is crucial for immanent critique in this respect: it means that the representation of discrepancy and contradiction is not merely an expression of historical reality but a force of change within it. 'Immanence' always-already implicates the historically poised, necessarily unfinished nature of human engagement, which suggests that the engagement is not something subjects can stand back from, but one that comes upon them with the "force of present distress' which they need to 'make rational'. ${ }^{58}$ The emphasis in all this is on the experiential dimension, the lived experience of suffering. 'I do not know', Horkheimer wrote, 'how far metaphysicians are correct ... But I do know that they are usually impressed only to the smallest degree by what men suffer.' 59 The incomprehensibility of suffering as such calls forth a response by the subject.

The response may take - and indeed, at least at first, it often does - the form of pure negation: an injunction that this is unjust. In an important essay, Paul Ricoeur identified that very injunction as one that crucially precedes the theories of justice that one might engage to justify it and lend it weight. 'The cry "it is unfair",' he writes, 'often indeed expresses a clearer intuition regarding the true nature of society and the place that violence still holds within it, than any discourse over what justice rationally or reasonably requires'.60 This temporal 'anomaly' connotes something important about the crucial function of negation as we developed it above. Let us return to it, now with the help of a real example.

In autumn 2005, the deaths of two young people in the Parisian suburb of Clichy-sous-Bois sparked rioting on an unprecedented scale. In a period of a few weeks the riots had spread to banlieues across France. In and around these suburban ghettos insurgent crowds burned cars, damaged buildings and clashed with police. The scale of the violence was such that it resulted in the French government's decision to implement emergency laws dating from the Algerian war of independence. The reactions from

\footnotetext{
57 ibid 241.

58 ibid, see 215 .

59 In Jay, The Dialectical Imagination, at p. 46.

60 This is what Paul Ricoeur says in a tantalisingly short extract from his L'acte de Juger: 'Nous n'accédons au sens de la justice que par le détour de la protestation contre l'injustice. Le cri: "C'est injuste!" exprime bien souvent une intuition plus clairvoyante concernant la nature véritable de la société, et la place qu'y tient encore la violence, que tout discours rationnel our raisonable sur la justice.' In Ricoeur, Le Juste, Paris, Esprit, 1995, p. 190.
} 
both government and public intellectuals were characteristically damning. For the prominent Gaullist intellectual Alain Finkielkraut, the riots sprang from a religiously motivated hate for the Republic; Nicolas Sarkozy, at the time Interior Minister, adopted 'warlike semantics', promising France that he would get rid of the 'thugs', the 'rabble' ('les débarrasser des voyous ... de la racaille') and using the metaphor of a 'Kärcher' (a high powered cleaning hose) when speaking of his intentions to clean the suburbs of the 'scum' inhabiting these areas. ${ }^{61}$

If on the one side the malaise des banlieues was offered only misrecognition ('religious hatred', 'thuggery'), if it was altogether denied the dignity of the signifier 'resistance' to the violence of systemic marginalisation that generated it, on the other side the normative dynamics of the uprisings were neither harnessed nor structured into meaningful political claim or strategy by the insurgents. Nor was there anything like collective agency. ${ }^{62}$ As far as the banlieusards were concerned, their action was played out on the field of negation: their objection to the advancing diminishment of life chances took the form of an objection - 'not this' - whose 'expression' was violence. A political claim for recognition had not yet been fashioned or articulated. We might venture the suggestion that the 'not yet' at stake here is the stake of critical theory. Since we have explored at some length above the meaning of negation and the forging of its own particular understanding of reflexivity at the juncture of theory and praxis, let us attempt to see how this might elucidate for us the meaning of the uprisings. What negation marks is a break with the understandings that have been offered to rationalise the situation. To borrow a formulation from the increasingly influential work of Jacques Rancière, it is a break with the available 'distribution of the sensible', the way in which political discourse attributes meaning to actions and events. But negation does not yet equip the insurgency with a 'scheme of interpretation' or of 'intelligibility'; it does not equip it with an alternative signification. At the level of negation it is merely a marker of a normative gap between the normative language available and a social experience of the diminishment of life chances. At one level, then, the insurgents' action is an injunction against the ways in which the available categories of political rationality (democracy, rights, equality) fail to collect rationally, and to give expression to, their experience as French citizens. This falling short of the categories available to signify the dispossession experienced registers only as a suffering that cannot find articulation. And the mobilisation, thematised from the point of view of political order (the 'order of the police', Rancière calls it) as a meaningless lashing out, has no language to dignify it as anything but that. This inadequacy walls in the suffering as necessary, written into the lives of the inhabitants of the ghettos, and immanent with the full weight of the impasse.

It is on this terrain that critical theory's promise of recuperation is inscribed. But inscription presupposes a register, and it finds it only in the categories (citizenship,

61 See Libération, 31 October 2005.

62 In his work on the sociology of the uprisings, Michel Kokoreff states that the riots 'ont marqué une entrée en politique des jeunes non seulement animés par le désir de détruire mais par une volonté de confrontation'. See Kokoreff, Michel, 'Sociologie de l'émeute. Les dimensions de l'action en question', Déviance et Société 30 (2006): 521-33, at 528 and Kokoreff, Michel, Sociologie des émeutes, Paris, Payot, 2008. 
rights, and so on) that the action attempts to place in doubt. This is the moment of immanent critique. It is immanent in the sense described above, as carried in the experience of the dispossessed, and thus engaging them normatively. And it is immanent, too, to the language available to describe that experience, the language of rights, democracy and equality. Its challenge is to articulate and exploit contradiction: that which erupted as negation seeks a register in a language that might rationalise it as the political order's simultaneous promise and denial of speaking position (citizenship) and claim (rights, equality, justice). Resistance seeks articulation in terms of the very categories that the action places in doubt. If the inscription succeeds, then it gains purchase in a system that promises but is incapable of delivering speaking position or justice to the insurgents, because its promise is undercut at the level of its material foundation of exploitative relations of capitalist production. 'Incapable' is an important word here; unlike 'likely', it carries a structural limitation. Equality is structurally undercut in a system that organises production along class lines: it is at once offered and denied; recognition is a lie where constituencies of the citizenry become superfluous as producers of value; less abstractly, a capitalist labour market cannot deliver on the promise of 'full employment' because a market - in order that it be able to optimise supply and demand - requires a structural element of unemployment to maintain itself as a market. In all these cases the promise hits upon a constitutive limitation, and in this respect, critique distinguishes itself from criticism as simply directed to rectify inconsistencies. ${ }^{63}$ In contrast, the object of critique is to expose contradiction and offers neither rectification nor reconciliation. It is instead poised against the 'wrong' where the wrong attaches to the very 'recognition order' that organises the semiotic field, and also the meaning of resistance to it. At this point the circle closes and theory fastens on to transformative praxis - because the solution has to be transcendent to the system that harboured it.

Is it incidental, then, that it is at this juncture that bourgeois theory most vocally rails against the connection of political action to suffering? The theoretical objection is raised with predictable anxiety whenever the solution is carried in the mode of engagement of those who have suffered the injustice on their skin, so to speak - from the 'sans-cullottes' who forced their wretchedness on the streets of Paris during the French Revolution, to the insurgents of the banlieues. Hannah Arendt warns repeatedly in On Revolution, with palpable alarm, that if you build a political theory on suffering, you end up with Robespierre and the Terror. It is a measure of her influence in the Anglo-American academy that this argument has been taken up as a credo by political theorists of the antidialectical bend; and yet all theoretical endeavour can and will be judged on its politics, even where its demand is presented, as so very eloquently in Arendt, at the metalevel of theory construction.

At this point we might conclude this short excursus with another reference to Marx on Feuerbach, this time the fourth thesis, where he writes about the 'cleavages and self-contradictions' that circulate at the level of secular society, a society 'both [to be] understood in its contradiction and revolutionized in practice'. Critical theory attempts

63 Rancière's distinction between politics/police is a powerful expression of the impasse that invites 'dissensus' as the form of its transcendence, while J-F Lyotard's Le Différend remains the most devastating account of the impossibility of such a move. 


\section{2}

to navigate this terrain of the nexus with praxis as appropriate to the conjunctures in which it finds itself. At no point has the reflexivity of theoretical reason lifted itself above history and the specific coordinates that determine the horizon of meaning. The first, semiotic, route took us through the processes of meaning construction, and the 'mediation' of factual situations through concepts that read them no longer as series of phenomena but as combinations, mediated and related within larger semantic fields and subfields. Critical thought found its opportunity in the irreducible contradictions that it attempted to 'bring to reason': contradictions between the promise of equality and the reproduction of an ever widening inequality; between the promise of inclusion and the reality of marginalisation; between the promise of dignity and the infliction of exploitation; between the promise to protect the right to work and the generalisation of job insecurity and underemployment, and so on. By tracking, fastening onto and 'exploiting' the contradictions that the imaginary constitution of society incurs, the critical method is able to engage actors normatively in forms of contestation of the reality of their situation. Negation, we saw, was a first step to resisting the necessity of the situation, and critique one to imagining the situation otherwise. And against the false givens of traditional theory, critical theory harboured 'the idea of a theory that becomes a 'genuine force,' revolutionising agency (or 'the self-awareness of the subjects' $)^{64}$ in the social dimension, and in the substantive dimension establishing that the theoretical elaboration of a state of affairs is indeed a step towards changing it.

\section{CRITICAL THEORY AND THE LAW}

This final section consists in a brief, suggestive rather than systematic, attempt to carry over some of the key insights of critical theory into legal thought. The history of critical legal theory as it emerged in Europe in the way described above ties it constitutively, on the one hand, to the state, as the form of the political organisation of society, and on the other to the political economy, as the site of its material reproduction. In reference to the state, critical theory thematises the institution of law as that which organises and mediates the relation of the state to civil society. The other constitutive reference, to the political economy, typically grounds this tradition of thinking about the law in the materiality of the practices of social production and reproduction. It is in these connections, of the institution of law to the domains of the state and of the political economy, that critical legal theory locates the function of law, with the emancipatory potential it affords on the one hand, and the obstacles to emancipation which it imposes on the other.

Neither of these two constitutive references - to the state and to material production - can be taken today to have the meaning they had for previous generations of critical theorists. The demand that theory confront its current historical conjuncture remains one of Marx's most valuable legacies, and such an effort today would demand that we turn - as far as the political economy is concerned - to the modalities and expressions

64 'La praxis qui révolutionne la realité' wrote the young Lukács in his Dialectique et Spontaneité, only recently unearthed (in 2001) in the ancient archives of the Lenin Institute in Moscow. 
of capitalist renewal, its new forms of flexible accumulation, the staggering growth of financialisation, the fragmentation of labour and the new forms of its exploitation, and so on, and - as far as the state is concerned - to the new functions of the state in the era of global flows, the new linkages of states and capitals, the articulations and disarticulations of state steering functions, and so on. As far as critical legal thinking is concerned, it involves a massive reorientation to the new modalities of organisation (and dispersal) of economic and political power.

How the organising categories of critical theory described above cross the institutional threshold into legal thinking is a question addressed across the range of the contributions to this book. Let me revisit briefly the key terms of our inventory (of section 2) in order to point out some possible connections, as well as the profound difficulty and effort it takes for critical theory to pierce the institutional veil. In each case the conceptual reach of the law and its connection to practice appears to be disciplined by law's function. And against this disciplining effect, the critical undertaking confronts particular difficulties that relate to the institutional nature of law.

First, critical theory's connection to praxis must negotiate what we might identify as the constitutive limitations of the institutional. Institutions reduce the contingency of human interaction; they entrench models of social relationships, and, in doing so, hedge in imaginative political uses and opportunities. To understand the law, it appears to be emphatically the case, is not to change it. Second, critical theory's dialectical imagination comes up again and again against the dominant (and severely antidialectical) paradigms, on the one hand, of its autonomous or 'pure' self-reproduction (Kelsen, Luhmann), and on the other, of its heteronomous dependence on politics and the exception (Schmitt, Agamben). Third, the very particular mediation of legal meaning is achieved through the ways in which it puts concepts in connection and in sequence and oversees application through the regulation of procedure. At once both enabling and limiting, these substantive and procedural rules deliver what Niklas Luhmann calls the 'reduction-achievement', which is law whose malleability is controlled through secondary rules that contain it and orient it to its proper function to channel and stabilise expectations. To secure this function the legal system needs to maintain a relative balance of stability and innovation, or, more precisely, to reproduce structures of normative expectations through controlled innovation. Innovations can only be grafted onto what already exists, and what already exists sets the thresholds of what might count as relevant information, what - and under what circumstances - may count as a 'surprise' in the system that might lead it to vary expectations. The legal observer will appreciate that the balanced renewal of law, of what is new and what business as usual, can only lean so far in the direction of variety without jeopardising the function of the law that must at some level meet the exigencies of the rule of law, and yield to protected expectations. Fourth, if genealogy calls us to unpick the law at the joints at which it establishes and renews its repertoire of reasons, it must first confront law's powers of 'homology' 65 and the unique methods it has to marshal the past in support of current arrangements, radically limiting our ability to reimagine or disentrench it except

65 I have discussed the mechanisms of 'homology' and 'deliberate deadlock' in a previous paper: Christodoulidis, E., 'Strategies of rupture', Law \& Critique 1 (2009). 


\section{Research handbook on critical legal theory}

in piecemeal ways. ${ }^{66}$ Because of course the law overwhelmingly reactivates known ground. The pattern of what can be varied, what contested comes heavily predetermined, not because the borders of law are heavily policed (though they are that too) but because structures of expectations release opportunities of variation selectively on the back of what is entrenched as invariant. Hovering above the reproduction of legal expectations along given pathways is the requirement of coherence, cutting away at genealogy at its core. Granted, there is nothing deterministic about the givenness of context (contexts are reconfigured as selections are made), but it is also counterproductive to exaggerate the leverage that critique is afforded under the conditions of normative closure and legal self-reference.

And yet, improbable as its conditions appear, critical theory has a vital role to play in legal thought, enhanced by the urgent need for its intervention in law's field of the reproduction of ideology and advantage. It is because law is steeped in tautology, paradox and contradiction that critical legal thinking can graft itself on the fault lines of law's articulations. ${ }^{67}$ Tautology is renewed in the grand positivisms of the day that define the law as what the law says it is, a circularity that becomes productive for the unity of the legal system at the point where rules lock into the system of law through (secondary or constitutional) rules that recognise them as rules. Critical theory might address these 'joints' at which the constitutional discourse walls itself in, in a gesture of immunisation. Paradox emerges as law's other-reference to the interests, persons and domains that it is called to regulate, mediated exclusively through its own selfreference. Contradictions emerge at the point at which the law, as tied to the processes of the material reproduction of society, couches in the universality of its categories the partiality of its distributions. Critical insight can address such operations, both where paradox institutes a gap and where contradiction conceals the elision it performs.

Let me end with three examples, three exemplary contradictions, with a view to identifying what the application of immanent critique might deliver in each case. The emphasis, remember, is on the experiential dimension. This is to say that legal actors confront the deficits in theory construction as experiential deficits, and therefore their engagement in the legal situation is not something that they can stand back from but is one that, remember, comes upon them with the 'force of present distress' which they need to 'make rational'. It is the lived dimension that is the potential site of disruption of the economy of representation that would otherwise organise meaning, seal it over and, in this state of self-immunisation, place it out of reach.

A first contradiction famously arises between constituent and constituted power. Here, pitched at the most abstract level of the constitutional register, a certain irresolution installs itself: constitution-making comes within a pregiven context of

66 Christopher Tomlins writes of 'a disenchanting mode of historical analysis, that strips [law] of its metaphysical dignity, unity, and coherence by exposing law as the outcome of mundane and profane processes and interests'. Tomlins, C., 'After critical legal history: scope, scale, structure', Annual Review of Law and Social Science 8 (2012): 31, 37.

67 I refer here to the way that Hans Lindahl develops the idea that 'questionability' grafts itself onto the faultlines of law to carve a space also for radical innovation. See Lindahl, Hans, Fault Lines of Globalization: Legal Order and the Politics of A-Legality, Oxford University Press, 2013. 
'recognition' that alone establishes its objective meaning as 'constitution'. Constitutional discourse thus forever folds back the constituent into the representational space of the constituted, which means that 'constituent power' comes harnessed to the constitutional order at the point of the very recovery of its meaning as constituent. A form of deadlock that is 'constitutive' of legal agency and legal opportunity underlines the constitution of democratic capitalism and leaves constitutively immune the regime of property and rights that it sanctions. To the extent that the articulation of the two moments is understood as giving expression to democratic constitutionalism, and it is this that provides the key ground of legitimacy to the constitutional order, immanent critique in this context would fasten onto the democratic dimension and insist on the transformative dimension of the democratic impulse as both promised and arrested in bourgeois constitutionalism. ${ }^{68}$

A second set of contradictions appears between categories of rights - civil, political and social. It is largely conceded in the literature that social rights are incongruous to capitalism and its particular structures of opportunity and reward, which accounts for the fact of their marginalisation, even eradication under austerity regimes, or their 'elevation' to aspirational status. Where the market does all the work of allocating value to resources among possible uses, the distribution of resources with the explicit aim to meet needs is, from the point of view of market thinking, irrational. What does it mean to insist on the incongruity, and to act on this assumed 'irrationality'? I have suggested that if social rights are beset by the contradiction between capitalism and democracy, we should explore the significance of their constitutional iteration, as enunciated - that is, with constitutional force - and as unyielding to their subjugation to the logic of civil and property rights. ${ }^{69}$ With the urgent appeal not to displace the antinomic significance of social constitutionalism, we might think of the use of immanent critique here as the insistent strategic use of social rights aiming to import a real contradiction from which the system cannot retract. ${ }^{70}$

A third example might focus on the use of immanent critique in terms of criminal procedure. The most spectacular instance relates to Jacques Vergès' 'strategy of rupture' in the context of the criminal trial. ${ }^{71}$ Vergès' defence of Nazi criminal Klaus Barbie before the French courts in 1987 consisted in the maximal use of the

68 See Lindahl, Hans, 'Possibility, actuality, rupture: constituent power and the ontology of change', Constellations 22:2 (2015): 163-74. Also Christodoulidis, E., 'Constitutional irresolution: law and the framing of civil society', European Law Journal 9:4 (2003), special issue: 401-32, and Christodoulidis, E., 'Against substitution: the constitutional thinking of dissensus', in Martin Loughlin and Neil Walker (eds) The Paradox of Constitutionalism: Constituent Power and Constitutional Form, Oxford University Press, 2007, pp. 189-208.

69 Christodoulidis, E., 'Social rights constitutionalism: an antagonistic endorsement', Journal of Law and Society 44.1 (2017): 123-49.

70 A Foucauldian reading of incongruity along these lines is suggested by Ben Golder: '[Foucault's] invocations of rights are strategic in this incongruous sense as they are situated within the spaces of political formation but are intended to resist and go beyond that formation, to transcend it.' In B. Golder, 'Foucault's critical (yet ambivalent) affirmation: three figures of rights', Social \& Legal Studies 20:3 (2011): 283-312, at 295.

71 Vergès, Jacques and Amar Bentoumi, De la stratégie judiciaire, Les éditions de minuit, 1968. 


\section{Research handbook on critical legal theory}

'tu quoque', in a way that would directly confront the French with their hypocritical denunciation of a crime that Vergès claimed underpinned their own colonial legacy and particularly the national policy during the Algerian War. The strategy of rupture aimed to undercut and reconfigure the historical and didactic nature of the trial, increase its responsive range, renegotiate past alliances and reopen wounds.

To conclude, let me recapitulate what I take to be features of critique that, in the Marxist tradition at least, identify it as immanent critique. Normative expectations are part of institutional frameworks that inform actors' perception of social reality. Immanent critique aims to generate within these institutional frameworks contradictions that are inevitable (they can neither be displaced nor ignored), compelling (they necessitate action) and transformative, in that (unlike internal critique) the overcoming of the contradiction does not restore, but transcends, the 'disturbed' framework within which it arose. Against 'hegemonic' reasoning, which allows legal reason to organise and reproduce meaning within given structures and thereby to secure those structures' continuation, critical theory pushes it to go beyond those patterns of reproduction and forces transgression, in a move that - to return to Marx, with whom we began - might 'enable the world to clarify its consciousness in waking it from its dream about itself' ${ }^{72}$

72 Letter to Arnold Ruge, September 1843. 